\title{
Variations in bacterial communities during foliar litter decomposition in the winter and growing seasons in an alpine forest of the eastern Tibetan Plateau
}

\begin{tabular}{|r|l|}
\hline Journal: & Canadian Journal of Microbiology \\
\hline Manuscript ID & cjm-2015-0448.R1 \\
\hline Manuscript Type: & Article \\
\hline Complete List of Authors: & O3-Oct-2015 \\
\hline & $\begin{array}{l}\text { Zhao, Yeyi; Long-term Research Station of Alpine Forest Ecosystems, } \\
\text { Institute of Ecology \& Forest, Sichuan Agricultural University; Collaborative } \\
\text { Innovation Center of Ecological Security in the Upper Reaches of Yangtze } \\
\text { River, } \\
\text { Wu, Fuzhong; Long-term Research Station of Alpine Forest Ecosystems, } \\
\text { Institute of Ecology \& Forest, Sichuan Agricultural University; Collaborative } \\
\text { Innovation Center of Ecological Security in the Upper Reaches of Yangtze } \\
\text { River, } \\
\text { Yang, Wanqin; Long-term Research Station of Alpine Forest Ecosystems, } \\
\text { Institute of Ecology \& Forest, Sichuan Agricultural University; Collaborative } \\
\text { Innovation Center of Ecological Security in the Upper Reaches of Yangtze } \\
\text { River, } \\
\text { Tan, Bo; Long-term Research Station of Alpine Forest Ecosystems, } \\
\text { Institute of Ecology \& Forest, Sichuan Agricultural University; Collaborative } \\
\text { Innovation Center of Ecological Security in the Upper Reaches of Yangtze } \\
\text { River, } \\
\text { He, Wei; Long-term Research Station of Alpine Forest Ecosystems, } \\
\text { Institute of Ecology \& Forest, Sichuan Agricultural University; Collaborative } \\
\text { Innovation Center of Ecological Security in the Upper Reaches of Yangtze } \\
\text { River, }\end{array}$ \\
\hline \multirow{2}{*}{ Keyword: } & $\begin{array}{l}\text { alpine forest, bacterial community, DGGE, foliar litter decomposition, q- } \\
\text { PCR }\end{array}$ \\
\hline & \\
\hline
\end{tabular}

\section{SCHOLARONE" \\ Manuscripts}


1 Variations in bacterial communities during foliar litter decomposition in

2 the winter and growing seasons in an alpine forest of the eastern Tibetan

3 Plateau

4

5 Yeyi Zhao ${ }^{1,2}$, Fuzhong $\mathrm{Wu}^{1,2}$, Wanqin Yang ${ }^{1,2 *}$, Bo Tan ${ }^{1,2}$, Wei He $\mathrm{He}^{1,2}$

6

7 Long-term Research Station of Alpine Forest Ecosystems, Institute of

8 Ecology \& Forest, Sichuan Agricultural University, Chengdu 611130,

9 China

$10{ }^{2}$ Collaborative Innovation Center of Ecological Security in the Upper

11 Reaches of Yangtze River, Chengdu 611130, China

$13 *$ Correspondence author: Wanqin Yang

14 E-mail: scyangwq@163.com

Tel: +86-28-86291112; Fax: +86-28-86290957

17 Yeyi Zhao, augustuszhao@gmail.com

18 Fuzhong Wu, wufzchina@163.com

19 Bo Tan, bobotan1984@163.com

20 Wei He, weihe19880408@gmail.com 
22 Abstract Bacterial communities are the primary engineers during litter

23 decomposition and related material cycling, and they can be strongly

24 controlled by seasonal changes in temperature and other environmental

25 factors. However, limited information is available on changes in the

26 bacterial community from winter to the growing season as litter

27 decomposition proceeds in cold climates. Here, we investigated the

28 abundance and structure of bacterial communities using real-time

29 quantitative PCR (q-PCR) and denaturing gradient gel electrophoresis

30 (DGGE) during a two-year field study of the decomposition of four litter

31 species in the winter and growing seasons of an alpine forest of the

32 eastern Tibetan Plateau. Although the abundance of bacterial 16S rRNA

33 gene during cypress and birch litter decomposition was relatively high in

34 the first winter, the abundance of other litters was significantly lower

35 relative to the growing season. A large number of bands were observed

36 on the DGGE gels, and the intensities and number of the bands from the

37 winter samples were lower compared with those from the growing season

38 during the two-year decomposition experiment. Eighty-nine sequences

39 from the bands of bacteria which had been cutted from DGGE gels were

40 affiliated with 10 distinct classes of bacteria and an unknown group. A

41 redundancy analysis indicated that the moisture, mass loss and elemental

42 content (e.g., $\mathrm{C}, \mathrm{N}$, and $\mathrm{P}$ ) of the litter significantly affected the bacterial

43 communities. Collectively, the results suggest that uneven seasonal 
44 changes in climate regulate bacterial communities and other decomposers, 45 thus affecting their contribution to litter decomposition processes in the 46 alpine forest.

47 Keywords alpine forest; bacterial community; DGGE; foliar litter 48 decomposition; q-PCR 


\section{Introduction}

Bacterial communities are the primary engineers during litter decomposition and are important in essential processes of biogeochemical cycles in terrestrial ecosystems (Jordan 1982; Aerts 1997; Didham 1998; Berg and McClaugherty 2008). However, bacteria are the most sensitive decomposer communities to changes in biotic and abiotic environments as microorganisms (Taylor et al. 2002; Young and Crawford 2004; Moscatelli et al. 2005; Monson et al. 2006). Minor changes in the environment often have strong effects on the structure and function of bacterial communities as well as on the decomposition of litter. Freezing temperatures in winter and warm temperatures in the growing season are the primary seasonal characteristics in cold climates; however, limited research has focused on seasonal changes in the bacterial community with litter decomposition.

The harsh environments in winter have long been considered to force microorganisms into dormancy or cause microorganism death (Uchida et al. 2005); thus, many studies have focused on bacterial communities in the growing season (Dilly et al. 2004; Korkama-Rajala et al. 2008; Thoms and Gleixner 2013). However, a growing number of cold-resistant bacterial groups were observed in winter beginning in the 1970s (Campbell et al. 2005; Zinger et al. 2009; Wang et al. 2010;

Wilhelm et al. 2011). Therefore, it has been suggested that these active 
bacterial populations might play an essential role in litter decomposition during winter.

Increasing evidence has shown that the loss of litter mass primarily occurs in the snow-covered season in cold biomes (Hobbie 1996; Aerts 1997, 2006; Konstantin 2010; Wu et al. 2013), which indicates that cold-adapted, cold-resistant and cryophilic microorganisms play important roles in litter decomposition in cold biomes. Recently, Zhu et al (2013) conducted a 2-year litter decomposition experiment along a subalpine forest gradient and demonstrated that the control of biological factors during litter decomposition in the growing season is significantly different from that in the non-growing season.

Cold biomes at high altitudes and latitudes are often characterized by obvious seasonal snow cover and freeze-thaw cycles. Baptist et al (2010) found that microorganisms and seasonal freeze-thaw cycles played significant roles in litter decomposition. Moreover, the biological activity of cold-adapted microorganisms has been detected in frozen soils (Clein and Schimel 1995), suggesting that litter decomposition in winter is primarily regulated by these microbes. During the growing season, favorable temperatures and humidity levels and adequate nutrient supply provide conditions for the proliferation and survival of most decomposers and lead to a diverse community structure that functions in the decomposition of litter. Compared with other microorganisms (such as 
93 fungi, actinomycetes and protozoan), bacteria often displays a much 94 stronger tolerance for cold temperatures and represent a major component 95 of the microbial communities during litter decomposition in alpine 96 regions (Neufeld et al. 2004; Mackelprang et al. 2011). Briefly, bacterial

communities in foliar litter might regulate litter mass loss at different critical periods in the growing and non-growing seasons in cold biomes. However, limited research has focused on the relationships between litter mass loss and bacterial communities at different periods in cold biomes.

The alpine forests located along the upper reaches of the Yangtze River and eastern Tibetan Plateau play important roles in storing fresh water, conserving soil and water, nurturing biodiversity, regulating regional climate, sequestering carbon dioxide, and providing climate change indicators (Liu 2002; Yang et al. 2005, 2006, 2007). In previous studies, microbial diversity has been observed in completely frozen soils in winter through the use of denaturing gradient gel electrophoresis (DGGE) and PCR (Liu et al. 2010; Wang et al. 2010; 2012), and the mass loss of foliar litter in winter was $40 \%$ to $65 \%$ of the total loss for the year (Wu et al, 2013). Moreover, although significant changes have been observed in the diversity of bacteria along with climate dynamics and freeze-thaw patterns in soil (Wang et al. 2010; Wang 2012) and bacterial activity may directly contribute to the decomposition of litter, these relationships have received little attention. Based on previous studies, it is 
115 hypothesized that the abundance, dominant groups and structure of

116 bacterial communities in foliar litter change as litter decomposition

117 proceeds, and these changes control the litter decomposition at different

118 critical periods in the growing and non-growing seasons in alpine forest

119 ecosystems.

120 To test these hypotheses, a field litterbag experiment was conducted

121 in a Mingjiang fir (Abies faxoniana) primary forest. DGGE and real-time

122 quantitative polymerase chain reaction (q-PCR) were used to evaluate the

123 changes in bacterial abundance and community structure that occur

124 during the decomposition of four different species of foliar litter

125 throughout the winter and growing seasons over 2 years. The results of

126 this study may clarify the mechanisms underlying bacterial

127 decomposition of foliar litter and provide further insight into the process

128 of foliar litter decomposition in alpine forests.

129 Materials and methods

\section{Site description}

131 The study was conducted in the Bipenggou Nature Reserve located

132 in Lixian County in southwestern China (E 102 $53^{\prime}-102^{\circ} 57^{\prime}$, N

$13331^{\circ} 14^{\prime}-31^{\circ} 19^{\prime} ; 2458-4619$ m.a.s.1.), which is in the transitional area

134 between the Sichuan Basin and Tibetan Plateau (Zhu et al. 2013). The

135 mean annual temperature of the study site is $2-4{ }^{\circ} \mathrm{C}$, the maximum 
136 temperature is $23{ }^{\circ} \mathrm{C}$, and the minimum temperature is $-18.0{ }^{\circ} \mathrm{C}$. The

137 annual precipitation is approximately $850 \mathrm{~mm}$. The soil is classified as

138 Cambic Umbrisol (IUSS Working Group WRB 2007) and has a pH of 6.2

$139 \pm 0.3$ (Gong et al. 2007). Snow cover remains for approximately 6 months

140 in the winter season. The sample sites were located in Daxuetang (E

$141102^{\circ} 53^{\prime}, \mathrm{N} 31^{\circ} 15^{\prime} ; 3582$ m.a.s.1.), which has an annual precipitation of

142 approximately $801 \mathrm{~mm}$ and mean annual temperature of $2.9{ }^{\circ} \mathrm{C}$. The

143 canopy vegetation is dominated by fir (Abies faxoniana), birch (Betula

144 albo-sinensis), larch (Larix mastersiana) and cypress (Sabina saltuaria).

145 The shade density is approximately 0.7 , and the average tree age is 130

146 years. The dominant understory plants are barberry (Berberis

147 sargentiana), sedge (Carex spp.), fern (Cystopteris montana), sheep

148 fescue (Festuca ovina), and azalea (Rhododendron delavayi) (Tan et al.

149 2014).

150 Foliar litter decomposition experiment

151 In September 2010, the fresh senescent foliar litter from larch, fir,

152 cypress and birch was collected from the forest floor at the sample sites.

153 The fresh foliar litter was air-dried for more than 2 weeks at room

154 temperature, the air-dried litter was weighed to determine the moisture

155 content, and the initial dry weight of the litter samples was determined by

156 oven drying $\left(65^{\circ} \mathrm{C}, 48 \mathrm{~h}\right)$. Samples of air-dried foliar litter were placed

157 inside nylon mesh bags $(20 \times 20 \mathrm{~cm} ; 0.055-\mathrm{mm}$ mesh sized nylon mesh 
158 of bags' bottom side; 1.0-mm mesh size nylon mesh of bags' top side;

$15910.00 \mathrm{~g}$ per bag) (Keane 2008; Xia et al. 2011), and a total of 240

160 litterbags $(3$ sample plots $\times 4$ species $\times 4$ sample dates $\times 5$ replicates $)$

161 were prepared. All of the litterbags with foliar litter were placed on the

162 forest floor under closed canopy in the sampled primary fir forests on

163 October 26, 2010, and intervals of at least 2-cm were placed between

164 each litterbag to avoid mutual disturbance upon collection (He et al. 2013;

165 Wu et al. 2013).

166 Based on previous studies, 3 sample plots $(25 \times 25 \mathrm{~m})$ with similar

167 environmental characteristics were randomly selected within the sampled

168 primary fir forests, and the plots were separated by at least $100 \mathrm{~m}$. To

169 determine the characteristics of bacterial abundance and community

170 structure in winter and the growing season during foliar litter

171 decomposition, the litterbags were collected on the following dates over

172 the 2-year experiment based on previous studies: March 3, $2011\left(1^{\text {st }}\right.$

173 winter stage, W1); August 19, 2011 (1 ${ }^{\text {st }}$ growing season, G1); March 7,

1742012 ( $2^{\text {nd }}$ winter, W2); and August 25, 2012 ( $2^{\text {nd }}$ growing season, G2).

175 Five litterbags were randomly collected from each of the sample sites on

176 each sample date and then immediately transported to the laboratory in

177 cold storage. Additionally, Thermochron iButton DS1923-F5 loggers

178 (Maxim Integrated, San Jose, USA) were set up on October 26, 2010 to

179 record the litterbag and air temperature every 2 hours (Figure 1). The 
180 positive accumulated temperature (PAT) and negative accumulated 181 temperature (NAT) were calculated, and $0{ }^{\circ} \mathrm{C}$ was considered the normal 182 threshold (Coakley et al. 1982) (Table 1).

183 Chemical analyses

184 Foreign materials such as roots and soil debris were carefully 185 removed from the litterbags. The samples were divided into two parts, 186 with one part used for the chemical analyses and mass loss measurements 187 and the other part used for bacterial community analyses. The loss of 188 foliar litter mass was calculated as follows: $M(g)=M_{0}-M_{t}$, where $M_{0}$ is 189 the dry litter mass when the bag was placed at the sample site $(\mathrm{g})$ and $\mathrm{M}_{\mathrm{t}}$ 190 is the mass of the dry litter from the litterbag after it was removed from 191 the site (g) (Zhu et al. 2012). The litterbag foliar litter was oven-dried at $19265^{\circ} \mathrm{C}$ for $48 \mathrm{~h}$ to a constant weight and then ground to pass through a 193 1-mm sieve to determine the total $\mathrm{C}$, total $\mathrm{N}$ and total $\mathrm{P}$ as described by $194 \operatorname{Lu}(1999)$.

195 DNA extraction and PCR and DGGE analyses

196 DNA was extracted from approximately $0.3 \mathrm{~g}$ (dry weight) of litter 197 using a DNA out kit (Tiandz, Beijing, China). The extracted DNA was 198 purified through agarose electrophoresis using an E.Z.N.A Gel Extraction 199 Kit (Omega Bio-Tek, Norcross, USA). The DNA purity was verified 200 using electrophoresis on a $1 \%$ agarose gel. For our community analysis, 201 DNA was pooled in equimolar amounts from the five replicates at each 
202 sample, species and sampling date combination to reduce the number of 203 samples and the variation across replicates (Stone et al. 2015).

204 The primer pair 341f (5'-CCTACGGGAGGCAGCCAG-3') and 205 534r (5'-ATTACCGCGGCTGCTGG-3') was selected based on the 206 conserved sequence of the V3 region of the 16S rRNA gene sequence to 207 amplify the bacterial gene fragments. The purified genomic DNA was 208 used as a template, and the $341 \mathrm{f}$ primer was modified with a GC-clamp: 209 CGCCCGCCGCGCCCCGCGCCCGGCCCGCCGCCCCCGCCCC

210 (Muyzer et al. 1993). To obtain the amplified target DNA, PCR was 211 performed using the $\mathrm{C} 1000^{\mathrm{TM}}$ Thermal Cycler (Bio-Rad, Hercules, CA, 212 USA) in $25 \mu \mathrm{L}$ reactions that contained $12.5 \mu \mathrm{L}$ Premix Ex Taq (TaKaRa, 213 Dalian, China), $0.4 \mathrm{mg} \cdot \mathrm{mL}^{-1}$ bovine serum albumin, $200 \mathrm{nmol} \cdot \mathrm{L}^{-1}$ each 214 primer, and $1.0 \mu \mathrm{L}$ purified DNA (1-10 $\mathrm{ng}$ ) as a template. The following 215 conditions were used for the PCR: initial denaturation at $94{ }^{\circ} \mathrm{C}$ for $5 \mathrm{~min}$, 21635 cycles of denaturation at $94{ }^{\circ} \mathrm{C}$ for $50 \mathrm{~s}$, annealing at $55^{\circ} \mathrm{C}$ for $60 \mathrm{~s}$, 217 chain extension at $72{ }^{\circ} \mathrm{C}$ for $50 \mathrm{~s}$, and a final extension step at $72{ }^{\circ} \mathrm{C}$ for $21815 \mathrm{~min}$. The GC-clamp product amplification was performed using a 219 C.B.S. Denaturing Gradient Gel Electrophoresis System (C.B.S. 220 Scientific Company, Inc.) according to the manufacturer's instructions. 221 The electrophoresis was performed using $10 \%$ acrylamide gels with a 222 denaturing gradient of $35-65 \%$. The PCR products $(25 \mu \mathrm{L})$ were used for 223 each DGGE analysis. Acrylamide gels were run in $1 \times$ TAE buffer (40 
$224 \mathrm{mmol} \cdot \mathrm{L}^{-1}$ Tris- $\mathrm{HCl}, 40 \mathrm{mmol} \cdot \mathrm{L}^{-1} \mathrm{CH}_{3} \mathrm{COOH}$, and $1 \mathrm{mmol} \cdot \mathrm{L}^{-1} \mathrm{EDTA} ; \mathrm{pH}$ $225=7.2$ ) at $60{ }^{\circ} \mathrm{C}$ for $16 \mathrm{~h}$ at $100 \mathrm{~V}$. The gels were stained with silver nitrate

226 and photographed with a GS- $800^{\mathrm{TM}}$ Calibrated Imaging Densitometer 227 (Bio-Rad), and the photographs were then digitized with Quantity One 228 4.0.1 (Bio-Rad) and the dominant DGGE bands were excised.....

229 Phylogenetic analysis of bacterial genes

230 Eighty-nine PCR products from the bands cut from the DGGE gels 231 were gel-purified and ligated into the pMD19-T vector (TaKaRa, Dalian, 232 China). The ligation products were cloned into Escherichia coli DH5 $\alpha$ 233 competent cells according to the manufacturer's instructions. After the 234 recombinant clones were reamplified using the vector-specific primer pair 235 M13-47 and RV-M (TaKaRa, Dalian, China), the identity of the positive 236 clones was validated through sequencing and the National Center for 237 Biotechnology Information (NCBI) Basic Local Alignment Search Tool 238 (BLAST) program for each sample date. The 16S rRNA gene sequences 239 identified from the samples were compared with related 16S rRNA gene 240 sequences in GenBank using the NCBI BLAST program (Altschul et al. 241 1990). Based on the nucleotide sequences, the phylogenetic analysis was 242 performed using MEGA (molecular evolutionary genetics analysis) 243 version 4.0 (Tamura et al. 2007), and neighbor-joining phylogenetic trees 244 were constructed from dissimilar distance and pairwise comparisons with the Kimura 2-parameter correction with 1000 replicates to produce the 
246 bootstrap values.

\section{Quantification of bacteria using q-PCR}

248 The PCR-amplified products were gel-purified and cloned as 249 described above. The ligation products were cloned into Escherichia coli 250 DH5 $\alpha$ competent cells according to the manufacturer's instructions. After 251 the recombinant clones were reamplified using the vector-specific primer 252 pair M13-47 and RV-M (TaKaRa, Dalian, China), the identity of the 253 positive clones was validated through sequencing and the National Center 254 for Biotechnology Information (NCBI) Basic Local Alignment Search 255 Tool (BLAST) program. The verified positive clones were selected for 256 plasmid DNA extraction using an E.Z.N.A Plasmid Extraction Kit 257 (Omega Bio-Tek), and these plasmids were used as the bacterial 16S 258 rRNA gene standards. A ultraviolet-visible (UV-VIS) BioPhotometer 259 (Eppendorf, Hamburg, Germany) was used to determine the 260 concentration of plasmid DNA, and the number of bacterial $16 \mathrm{~S}$ rRNA 261 gene copies was directly calculated from the concentration of the 262 extracted plasmid DNA (Okano et al. 2004). Tenfold serial dilutions of a 263 known number of copies of the plasmid DNA that contained the 264 sequenced bacterial $16 \mathrm{~S}$ rRNA gene fragments were subjected to q-PCR 265 in triplicate to generate an external standard curve.

266 Bacterial 16S rRNA gene from the purified foliar litter sample DNA 267 was amplified by PCR using the primer pair Eub 338 
268 (5'-ACTCCTACGGGAGGCAGCAG-3') and ${ }^{\prime}$ Eub 518

269 (5'-ATTACCGCGGCTGCTGG-3') (Lane 1991). The q-PCR was

270 performed in $20 \mu \mathrm{L}$ reactions that contained $12.5 \mu \mathrm{L}$ SsoFast $^{\mathrm{TM}}$ Eva

271 Green Supermix (Bio-Rad), $0.4 \mathrm{mg} \cdot \mathrm{mL}^{-1}$ bovine serum albumin, 200

$272 \mathrm{nmol} \cdot \mathrm{L}^{-1}$ each primer, and $1.0 \mu \mathrm{L}$ purified foliar litter sample DNA (1-10

$273 \mathrm{ng}$ ) as a template with the $\mathrm{CFX}^{\mathrm{TM}}$ Real-Time system (Bio-Rad).

274 Triplicate replicates were analyzed for each sample, and the optimized

275 reaction conditions were as follows: pre-denaturation at $98{ }^{\circ} \mathrm{C}$ for $30 \mathrm{~s} ; 35$

276 cycles of denaturation at $98{ }^{\circ} \mathrm{C}$ for $10 \mathrm{~s}$, annealing at $54{ }^{\circ} \mathrm{C}$ for $30 \mathrm{~s}$, and

277 extension at $72{ }^{\circ} \mathrm{C}$ for $30 \mathrm{~s}$. The plates were read at $72{ }^{\circ} \mathrm{C}$ after each cycle,

278 and the product specificity was confirmed using a melting curve analysis

$279\left(65-95^{\circ} \mathrm{C}, 0.5^{\circ} \mathrm{C}\right.$ per read with a hold time of $\left.5 \mathrm{~s}\right)$.

\section{Statistical analyses}

281 The digital images of the DGGE gels were obtained and analyzed

282 using the Quantity One 4.0.1 software (Bio-Rad). Densitometric data

283 obtained from the DGGE images were used to perform a principal

284 component analysis (PCA) and multivariate redundancy analysis (RDA)

285 with CANOCO 4.5 for Windows (Wageningen UR, Netherlands).

286 Correlations between the bacterial abundance and foliar litter mass loss,

287 litter elemental composition and environmental factors were analyzed

288 using Pearson's correlation coefficients in SPSS statistical software

289 (version 20.0, IBM, USA). 


\section{Nucleotide sequence accession numbers}

The 16S rRNA gene sequences obtained in this study were deposited in GenBank and were the following accession numbers: KJ 616619, KJ 616622-616624, KJ616640-KJ616652, KR 707618-KR707684.

\section{Results}

\section{Bacterial abundance}

Over the 2-year decomposition, the number of bacterial 16S rRNA gene copies was $1.34 \times 10^{6}-1.26 \times 10^{9} \mathrm{~g}^{-1}$ dry litter for larch, $7.45 \times$ $10^{6}-7.55 \times 10^{8} \mathrm{~g}^{-1}$ dry litter for fir, $2.99 \times 10^{7}-6.49 \times 10^{9} \mathrm{~g}^{-1}$ dry litter for cypress and $1.92 \times 10^{8}-1.47 \times 10^{10} \mathrm{~g}^{-1}$ dry litter for birch (Figure 2). The abundance of bacterial 16S rRNA gene copies in the cypress and birch litter in winter was the highest at W1, whereas larch and fir litter had the highest abundance on G1, with this value subsequently decreasing to a minimum at W2 except for birch, which presented the lowest abundance at G2. The number of bacterial 16S rRNA gene copies was significantly correlated with the total $\mathrm{P}, \mathrm{C} / \mathrm{N}, \mathrm{C} / \mathrm{P}$ and $\mathrm{N} / \mathrm{P}$ in all seasons, and temperature influenced the abundance of bacteria throughout the experiment (Table 2). In summary, the abundance of bacteria was lower in the $2^{\text {nd }}$ year compared with the $1^{\text {st }}$ year.

\section{Diversity and dynamics of the bacterial community}

Significant differences were observed in the structure of the bacterial 
311 community in the four different types of foliar litter during the

312 decomposition process in winter and the growing seasons. The number

313 and intensity of the bands were lower in winter relative to the growing

314 season, and certain bands disappeared completely (Figure 3); however,

315 only the number of birch litter bands was greater in winter compared with

316 the other stages in the $2^{\text {nd }}$ year (Table 3 ). In comparison between winter

317 and the growing seasons, the Shannon-Wiener indices were lower in

318 winter and inversely related to variations in the Simpson indices generally,

319 but there were inversely with cypress and birch in the $2^{\text {nd }}$ years (Table 3 ).

320 To provide a more effective analysis of the bacterial community

321 composition at two different stages during foliar litter decomposition as

322 well as the DGGE band intensity, a PCA was performed to determine the

323 degree of similarity among samples in the winter and growing seasons.

324 The first two PCA factors accounted for $69.8 \%$ of the variability (Figure

3254 ), and variations were observed in the bacterial community between the

326 winter and growing seasons, although the communities were similar

327 during the foliar litter decomposition process. Additionally, the foliar

328 litter species acting as substrates affected the bacterial community.

\section{Phylogenetic analysis}

330 Using the sequences from the primary bands, all of the bacterial

331 sequences were grouped into ten distinct classes (Actinobacteria,

332 Alphaproteobacteria, Bacilli, Betaproteobacteria, Deltaproteobacteria, 
333 Epsilonproteobacteria, Flavobacteria, Gammaproteobacteria, and 334 Sphingobacteria) as well as an unclassified group based on 335 neighbor-joining phylogenetic trees (Figure 5). The composition of these 336 bacterial groups varied notably between the winter and growing seasons

337 (Figure 6). Gammaproteobacteria dominated in winter largely in the larch 338 and cypress litters, whereas Alphaproteobacteria and Sphingobacteria

339 dominated in the $1^{\text {st }}$ and $2^{\text {nd }}$ growing seasons, respectively, in fir litter and 340 were the dominant groups in the birch litter decomposition process, 341 although their abundance was variable in the different stages. The 342 bacterial community structure in winter was simpler than that in the 343 growing season.

344

\section{Redundancy analysis}

The multivariate RDA showed that environmental factors and foliar litter elemental contents regulated the dynamics of the bacterial community structure (Figure 7), and the primary factor varied with the different stages of the litter decomposition process. In the $1^{\text {st }}$ winter, the moisture was correlated with Alphaproteobacteria, mass loss was correlated with Betaproteobacteria, Gammaproteobacteria and Sphingobacteria, and the $\mathrm{C} / \mathrm{N}$ ratio affected Flavobacteria. In the $2^{\text {nd }}$ winter, moisture was the primary influencing factor on Betaproteobacteria, Flavobacteria and Sphingobacteria, and the mass loss and total $\mathrm{C}$ content were correlated with Alphaproteobacteria and Gammaproteobacteria, 
355 respectively. In the $1^{\text {st }}$ growing season, Actinobacteria, Bacilli,

356 Deltaproteobacteria and Epsilonproteobacteria were affected by the total

$357 \mathrm{P}$ content and $\mathrm{C} / \mathrm{P}$, Alphaproteobacteria and Gammaproteobacteria and

358 Flavobacteria were correlated with moisture, and Sphingobacteria were

359 affected by the total C content. Moreover, the Bacilli,

360 Epsilonproteobacteria and Flavobacteria were significantly affected by

361 the total $\mathrm{N}$ content, the moisture was correlated with the

362 Gammaproteobacteria and Sphingobacteria, $\mathrm{C} / \mathrm{P}$ and the total $\mathrm{C}$ were

363 correlated with Actinobacteria and Alphaproteobacteria respectively.

\section{Discussion}

365 Two combined analysis methods were used here to explore the bacterial

366 abundance and community composition of four litter species throughout

367 2-year decomposition process in an alpine forest. Relatively abundant

368 groups of bacteria were detected during foliar litter decomposition in

369 winter, and bacterial abundance and community composition were

370 influenced by variations in the moisture and elemental contents in the

371 litter $(\mathrm{C}, \mathrm{N}$ and $\mathrm{P})$ in both the winter and growing seasons. These results

372 support our hypothesis that the abundance, dominant groups and structure

373 of bacterial communities in foliar litter change as litter decomposition

374 proceeds, and these changes control the litter decomposition at different

375 critical periods in the growing and non-growing seasons in alpine forest 
376

377

378

379

380

ecosystems.

Bacteria survive in subzero temperatures and remain active at extreme cold temperatures (Carpenter et al, 2000; Junge et al, 2002). The bacterial community is an important part of the overall decomposer community and actively participates in the process of foliar litter decomposition. With continued foliar litter decomposition, seasonal variations in the number of bacterial $16 \mathrm{~S}$ rRNA gene copies reflected the dynamics of bacterial abundance, and a statistical analysis of the q-PCR results indicated that variations in bacterial abundance were related to variability in environmental factors and elemental litter contents. The environment in winter, including freeze-thaw cycles, is particularly damaging to microorganisms (Walker et al, 2006) because of the formation of ice and reduction in soil solute concentrations, which result in protein denaturation, cell dehydration and low metabolic rates (Nedwell, 1999; Rodrigues and Tiedje, 2008). In general, low temperatures reduce microbial diversity and even kill certain bacteria species that have poor cold tolerance. Therefore, bacterial abundance should increase from winter to the growing season in cold regions (Deslippe et al. 2012), and higher abundances of bacteria should be observed during the growing season. Although the abundance of bacteria in larch and fir litter increased from winter to the growing season throughout the experiment, abundance was observed to decrease in the 
cypress and birch litters from the $1^{\text {st }}$ winter to the growing season, which may be explained by several possible underlying mechanisms. First, the lack of a snowpack during winter exposed the litter to extreme environmental conditions (e.g., large diurnal temperature changes); therefore, the region did not experience a relatively stable environment required to maintain bacterial activity in winter (Drotz et al. 2010; Bokhorst et al. 2010). Second, the foliar litter substrate on the forest floor, which lacked the protection of the snowpack, experienced increased mechanical disruption from the freeze events and freeze-thaw cycles in the winter, which resulted in an improved substrate environment for bacteria because of the greater availability of microbial substrates in the subsequent growing season (Berg 2000; Groffman et al. 2001; Herrmann and Witter 2002; Hentschel et al. 2008). Third, after the $1^{\text {st }}$ year of decomposition, labile constituents were decomposed, which reduced the availability of nutrients required to sustain bacterial activities in the subsequent year (Dijkstra et al, 2011; Cotrufo et al, 2013). Fourth, the available nutrients decreased with the litter mass loss and might have been leached into the soil by rainfall (Wu et al, 2013); in addition, this loss may have been greater with the broad-leaved litter compared with the needle litter, which could explain the reduced abundance of bacteria in birch litter in the $2^{\text {nd }}$ year of this study (Neff and Asner 2001; Park and Matzner 2003; Müller et al. 2009). 
The diversity indices and bacterial group variations were direct

421 indicators of bacterial community responses to the decomposition process

422 of foliar litter. The Shannon-Wiener indices and Simpson indices were

423 notably lower and higher, respectively, in winter compared with the

424 growing season, and the values were consistent with the results for

425 bacterial abundance. Although a large number of bacteria might have

426 been killed and the Shannon-Wiener diversity index of the bacterial

427 community was notably reduced in winter, certain bacterial species might

428 increase their predominance in the community because of high tolerance

429 for harsh environmental conditions (Walker et al. 2006; Wilson and

430 Walker 2010). In addition, broad-leaved litter under freeze-thaw cycles

431 can provide additional substrates for bacterial groups in winter, and

432 improved environmental conditions, including sufficient moisture and

433 mechanical disruptions of the litter caused by repeated freeze-thaw cycles,

434 provide abundant substrates in the growing season and a good

435 environment for bacterial communities (Lipson and Schmidt 2004);

436 however, the low exchange of nutrients and water availability with longer

437 periods of winter may present a greater stress to bacteria (Morozova and

438 Wagner, 2007). Changes in the relative abundance of the bacterial groups

439 during foliar litter decomposition (Figure 6) highlight the importance of

440 understanding the relationships between changes in bacterial communities

441 and environmental factors. The elemental contents, litter mass loss and 
442 temperature during foliar litter decomposition might change the bacterial 443 community structure. Based on a comparison of the results with the NCBI, 444 the bacterial groups included Actinobacteria, Alphaproteobacteria, Bacilli, 445 Betaproteobacteria, Deltaproteobacteria, Epsilonproteobacteria, 446 Flavobacteria, Gammaproteobacteria, and Sphingobacteria. The bands 447 from the winter DGGE gels were consistent with Pseudomonas 448 (Gammaproteobacteria) in foliar litter, which was detected from alpine and glacial environments in other studies, indicating that these species 450 can better tolerate the harsh environmental conditions during winter 451 (Shivaji et al. 2004; Jiang et al. 2006; Zinger et al. 2009; Swan et al. 452 2010). However, Gammaproteobacteria reduced in the broad-leaf birch 453 litter in this present study. Moreover, the bacterial communities in the 454 subsequent growing season and winter were abundant, which suggests 455 that the surviving and cold-active bacteria, which were masked by the more abundant species, adjusted their metabolic profiles (Nedwell, 1999;

457 Schimel et al, 2007) in the subsequent growing season and winter. The 458 multivariate RDA was used to illustrate the relationships between the 459 bacterial community structure and environmental factors during foliar 460 litter decomposition (Figure 7). The elemental contents, mass loss and 461 moisture affected the bacterial community structure, although various 462 primary factors affected the dominant groups of bacteria. In the $1^{\text {st }}$ winter, 463 the mass loss and elemental contents of the litter were the primary factors 
464 limiting Gammaproteobacteria, which was the primary bacterial group. In

465 the $2^{\text {nd }}$ year, the moisture and elemental contents were the primary factors

466 that affected the dominant groups. In the growing season, however, the

467 dominant groups of bacteria were correlated with moisture (Figure 7).

468 In summary, the relatively rich abundance of bacteria detected in

469 winter was notable and highlighted changes in the bacterial community

470 structure between the winter and growing seasons during foliar litter

471 decomposition. Changes in the loss of mass, moisture, and elemental

472 contents in foliar litter are significantly related to the abundance and

473 community composition of bacteria. Foliar litter substrates and

474 environmental factors affected the bacterial community structure, which

475 might have significance for understanding the process of foliar litter

476 decomposition in the cold biomes. In the future, we should pay more

477 attention to seasonal fluctuations of microorganisms and their related

478 influencing factors as litter decomposition proceeds in the alpine forest.

479 In addition to that, further more advanced methods should be used to

480 study the microorganisms inorder to clearly understand their abundance, 481 distribution and functions in litter decomposition.

\section{Acknowledgments}

484 We gratefully acknowledge the reviewer and editor for their constructive 
485 comments and suggestions. This research was conducted in compliance 486 with the laws of the People's Republic of China, and the study was 487 financially supported by the National Natural Science Foundation of 488 China (31170423 and 31270498), National Key Technologies R\&D in 489 China (2011BAC09B05), Sichuan Youth Sci-tech Foundation 490 (2012JQ0008 and 2012JQ0059) and China Postdoctoral Science 491 Foundation (2012T50782). We are very grateful to Qiqian Wu for the nice 492 suggestions on the manuscript, and to Chunzi Wang for the help in 493 laboratory analysis work. 
494

495

496

497

498

499

500

501

502

503

504

505

506

507

508

509

510

511

512

513

514

515

516

517

518

\section{References}

Aerts, R. 1997. Climate, leaf litter chemistry and leaf litter decomposition in terrestrial ecosystem: a triangular relationship. Oikos 79:439-449.

Aerts, R. 2006. The freezer defrosting: global warming and litter decomposition rates in cold biomes. J. Ecol. 94:713-724.

Altschul, S.F, Gish, W., Miller, W., Myers, E.W., Lipman, D.J. 1990. Basic local alignment search tool. J. Mol. Bio. 215:403-410.

Baptist, F., Yoccoz, N.G., Choler, P. 2010. Direct and indirect control by snow cover over decomposition in alpine tundra along a snowmelt gradient. Plant. Soil. 328:397-410.

Berg, B., and McClaugherty, C. 2008. Plant Litter: Decomposition, Humus Formation, Carbon Sequestration, 2nd ed. Springer, New York, NY.

Berg, B. 2000. Litter decomposition and organic matter turnover in northern forest soils. Forest. Ecol. Manag. 133:13-22.

Bokhorst, S., Bjerke, J.W., Melillo, J., Callaghan, T.V., Phoenix, G.K. 2010. Impacts of extreme winter warming events on litter decomposition in a Sub-Arctic heathland. Soil. Biol. Biochem. 42:611-617.

Campbell, J.L., Mitchell, M.J., Groffman, P.M., Christenson, L.M., Hardy, J.P. 2005.

Winter in northeastern North America:a critical period for ecological processes. Front. Ecol. Environ. 3:314-322.

Carpenter, E.J., Lin, S., Capone, D.G. 2000. Bacterial activity in South Pole snow. Appl. Environ. Microbiol. 66:4514-4517.

Clein, J.S., and Schimel, J.P. 1995. Microbial activity of tundra and taiga soils at sub-zero temperatures. Soil. Biol. Biochem. 27:1231-1234.

Coakley, S.M., Boyd, W.S., Line, R.F. 1982. Statistical models for predicting stripe 
519 rust on winter wheat in the Pacific Northwest. Phytopathology. 72:1539-1542.

520 Cotrufo, M.F., Wallenstein, M.D., Boot, C.M., Denef, K., Paul, E. 2013. The

521 Microbial Efficiency-Matrix Stabilization (MEMS) framework integrates plant litter

522 decomposition with soil organic matter stabilization: do labile plant inputs form stable

523 soil organic matter? Global Change Biology. 19(4):988-995.

524 Deslippe, J.R., Hartmann, M., Simard, S.W., Mohn, W.W. 2012. Long-term warming 525 alters the composition of Arctic soil microbial communities. FEMS. Microbiol. Ecol.

$526 \quad \mathbf{8 2 : 3 0 3 - 3 1 5 .}$

527 Didham, R.K. 1998. Altered leaf-litter decomposition rates in tropical forest 528 fragments. Oecologia. 116:397-406.

529 Dijkstra, P., Thomas, S.C., Heinrich, P.L., Koch, G.W., Schwartz, E., Hungate, B.A. 530 2011. Effect of temperature on metabolic activity of intact microbial communities: 531 evidence for altered metabolic pathway activity but not for increased maintenance 532 respiration and reduced carbon use efficiency. Soil. Biol. Biochem. 43(10):2023-2031. 533 Dilly, O., Bloem, J., Vos, A., Munch, J.C. 2004. Bacterial diversity in agricultural soils 534 during litter decomposition. Appl. Environ. Microbiol. 70:468-474.

535 Drotz, S.H., Sparrman, T., Nilsson, M.B., Schleucher, J., Öquist, M.G. 2010. Both 536 catabolic and anabolic heterotrophic microbial activity proceed in frozen soils. Proc. 537 Natl. Acad. Sci. 107:21046-21051.

538 Gong, Z.T., Zhang, G.L., Chen, Z.C. 2007. Pedogenesis and soil taxonomy. (Chinese.) 539 Beijing Sci. Press Publ., Beijing.

540 Groffman, P.M., Driscoll, C.T., Fahey, T.J., Hardy, J.P., Fitzhugh, R.D., Fierney, G.L. 541 2001. Effects of mild winter freezing on soil nitrogen and carbon dynamics in 542 northern hardwood forest. Biogeochemistry. 56:191-213.

543 He, W., Wu, F.Z., Yang, W.Q., Wu, Q.Q., He, M., Zhao, Y.Y. 2013. Effect of snow 
544 patches to mass loss of two shrubs leaf litter in alpine forest. Chine. J. Plant. Ecol.

$545 \quad 37: 306-316$.

546 Hentschel, K., Borken, W., Matzner, E. 2008. Repeated freeze-thaw events affect

547 leaching losses of nitrogen and dissolved organic matter in a forest soil. J. Plant. Nutr.

548 Soil. Sc. 171:699-706.

549 Herrmann, A., and Witter, E. 2002. Sources of C and N contributing to the flush in

550 mineralization upon freeze-thaw cycles in soils. Soil. Biol. Biochem. 34:1495-1505.

551 Hobbie, S.E. 1996. Temperature and plant species control over litter decomposition in 552 Alaskan tundra. Ecol. Mono. 66:503-522.

553 IUSS Working group WRB. 2007. World Reference Base for Soil Resources 2006,

554 First Update 2007. World Soil Resources Report No. 103.

555 Jiang, H., Dong, H., Zhang, G., Yu, B., Chapman, L.R., Fields, M.W. 2006. Microbial

556 diversity in water and sediment of Lake Chaka, an athalassohaline lake in

557 northwestern China. Appl. Environ. Microbiol. 72:3832-3845.

558 Jordan, C.F. 1982. The nutrient balance of an Amazonian rain forest. Ecology. 559 63:647-654.

560 Junge, K., Imhoff, F., Staley, T., Deming, J.W. 2002. Phylogenetic diversity of 561 numerically important Arctic Sea-ice bacteria at subzero temperature. Microb. Ecol. $562 \quad 43: 315-328$.

563 Keane, R.B. 2008. Biophysical controls on surface fuel litterfall and decomposition in 564 the northern Rocky Mountains, USA. Can. J. Forest. Res. 38:1431-1445.

565 Konstantin, S.G. 2010. Dynamics of alpine plant litter decomposition in a changing 566 climate. Plant. Soil. 337:19-32.

567 Korkama-Rajala, T., Müller, M.M., Pennanen, T. 2008. Decomposition and fungi of 568 needle litter from slow-and fast-growing Norway spruce (Picea abies) clones. Microb. 
Ecol. 56:76-89.

Lane, D.J. 1991. 16S/23S rRNA sequencing. In: E. Stackebrantd and M. Goodfellow (Eds.) Nucleic acid techniques in bacterial systematics. Wiley, Chichester, UK. $125-175$.

Lipson, D.A., and Schmidt, S.K. 2004. Seasonal changes in an alpine soil bacterial community in the Colorado Rocky Mountains. Appl. Environ. Microbiol. 70:2867-2879.

Liu, L., Wu, F.Z., Yang, W.Q., Wang, A., Tan, B., Yu, S. 2010. Soil bacterial diversity in the subalpine/alpine forests of western Sichuan at the early stage of freeze-thaw season. Acta. Ecologica. Sinica. 30:5687-5694.

Liu, Q. 2002. Ecological research on Subalpine Coniferous Forests in China. Chengdu, Sichuan University Press.

Lu, R.K. 1999. Soil and agro-chemical analytical methods. China Agricultural Science and Technology Press, Beijing. 227-448.

Mackelprang, R., Waldrop, M.P., DeAngelis, K.M., David, M.M., Chavarria, K.L., Blazewicz, S.J., Jansson, J.K. 2011. Metagenomic analysis of a permafrost microbial community reveals a rapid response to thaw. Nature. $\mathbf{4 8 0}: 368-371$.

Monson, R.K., Lipson, D.L., Burns, S.P., Turnipseed, A.A., Delany, A.C., Williams, M.W., Schmidt, S.K. 2006. Winter forest soil respiration controlled by climate and microbial community composition. Nature. 439:711-714.

Morozova, D., and Wagner, D. 2007. Stress response of methanogenic archaea from Siberian permafrost compared with methanogens from nonpermafrost habitats. FEMS Microbiol. Ecol. 61:16-25.

Moscatelli, M., Lagomarsino, A., Marinari, S., De Angelis, P., Grego, S. 2005. Soil microbial indices as bioindicators of environmental changes in a poplar plantation. 
594 Ecol. Indic. 5:171-179.

595 Müller, M., Alewell, C., Hagedorn, F. 2009. Effective retention of litter-derived 596 dissolved organic carbon in organic layers. Soil. Biol. Biochem. 41:1066-1074.

597 Muyzer, G., De Waal, E.C., Uitterlinden, A.G. 1993. Profiling of complex microbial 598 populations by denaturing gradient gel electrophoresis analysis of polymerase chain 599 reaction-amplified genes coding for $16 \mathrm{~S}$ rRNA. Appl. Environ. Microbiol. $600 \quad 59: 695-700$.

601 Nedwell, D.B. 1999. Effects of low temperature on microbial growth: lowered affinity 602 for substrates limits growth at low temperatures. FEMS. Microbiol. Ecol. 30:101-111. 603 Neff, J.C., and Asner, G.P. 2001. Dissolved organic carbon in terrestrial ecosystems: 604 synthesis and a model. Ecosystems. 4:29-48.

605 Neufeld, J.D., Yu, Z., Lam, W., Mohn, W.W. 2004. Serial analysis of ribosomal 606 sequence tags (SARST): a high-throughput method for profiling complex microbial 607 communities. Environ. Microbiol. 6:131-144.

608 Okano, Y., Hristova, K.R., Leutenegger, C.M., Jackson, L.E., Denison, R.F., 609 Gebreyesus, B., Scow K.M. 2004. Application of real-time PCR to study effects of 610 ammonium on population size of ammonia-oxidizing bacteria in soil. Appl. Environ. 611 Microbiol. 70:1008-1016.

612 Park, J.H., Matzner, E. 2003. Controls on the release of dissolved organic carbon and 613 nitrogen from a deciduous forest floor investigated by manipulations of aboveground 614 litter inputs and water flux. Biogeochemistry. 66:265-286.

615 Rodrigues, D.F., and Tiedje, J.M. 2008. Coping with our cold planet. Appl. Environ. 616 Microbiol. 74:1677-1686.

617 Schimel, J., Balser, T.C., Wallenstein, M. 2007. Microbial stress-response physiology 618 and its implications for ecosystem function. Ecology. 88:1386-1394. 
619 Shivaji, S., Reddy, G.S., Aduri, R.P., Kutty, R., Ravenschlag, K. 2004. Bacterial

620 diversity of a soil sample from Schirmacher Oasis, Antarctica. Cell. Mol. Biol. $621 \quad \mathbf{5 0}: 525-536$.

622 Stone, M.M., Kan, J.J., Plante, A.F. 2015. Parent material and vegetation influence 623 bacterial community structure and nitrogen functional genes along deep tropical soil 624 profiles at the Luquillo Critical Zone Observatory. Soil. Biol. Biochem. 80: 273-282. 625 Swan, B.K., Ehrhardt, C.J., Reifel, K.M., Moreno, L.I., Valentine, D.L. 2010. 626 Archaeal and bacterial communities respond differently to environmental gradients in 627 anoxic sediments of a California hypersaline lake, the Salton Sea. Appl. Environ. 628 Microbiol. 76:757-768.

629 Tamura, K., Dudley, J., Nei, M., Kumar, S. 2007. MEGA4:molecular evolutionary 630 genetics analysis (MEGA) software version 4.0. Mol. Biol. Evol. 24:1596-1599.

631 Tan, B., Wu, F.Z., Yang, W.Q., He, X.H. 2014. Snow removal alters soil microbial 632 biomass and enzyme activity in a Tibetan alpine forest. Appl. Soil. Ecol. 76:34-41.

633 Taylor, J.P., Wilson, B., Mills, M.S., Burns, R.G. 2002. Comparison of microbial 634 numbers and enzymatic activities in surface soils and subsoils using various 635 techniques. Soil. Biol. Biochem. 34:387-401.

636 Thoms, C., and Gleixner, G. 2013. Seasonal differences in tree species' influence on 637 soil microbial communities. Soil. Biol. Biochem. 66:239-248.

638 Uchida, M., Mo, W., Nakatsubo, T., Tsuchiya, Y., Horikoshi, T., Koizumi, H. 2005.

639 Microbial activity and litter decomposition under snow cover in a cool-temperate 640 broad-leaved deciduous forest. Agr. Forest. Meteorol. 134:102-109.

641 Walker, V.K., Palmer, G.R., Voordouw, G. 2006. Freeze-thaw tolerance and clues to 642 the winter survival of a soil community. Appl. Environ. Microbiol. 72:1784-1792.

643 Wang, A., Zhang, J., Yang, W.Q., Wu, F.Z., Liu, L., Tan, B. 2010. Bacterial diversity 
644 in organic soil layers of subalpine and alpine forests at the end of freeze-thaw periods. 645 Journal of Beijing Forestry University 32:144-150.

646 Wang, A. 2012. Effect of seasonal freeze-thaw on soil microbial and biochemical 647 property in alpine forest soil (Doctoral dissertation, Sichuan Agricultural University). 648 Wang, A., Wu, F.Z., Yang, W.Q., Wu, Z.C., Wang, X.X., Tan B. 2012. Abundance and 649 composition dynamics of soil ammonia-oxidizing archaea in an alpine fir forest on the 650 eastern Tibetan Plateau of China. Can. J. Microbiol. 58:572-580.

651 Wilhelm, R.C., Niederberger ,T.D., Greer, C., Whyte, L.G. 2011. Microbial diversity 652 of active layer and permafrost in an acidic wetland from the Canadian High Arctic. 653 Can. J. Microbiol. 57:303-315.

654 Wilson, S.L., and Walker, V.K. 2010. Selection of low-temperature resistance in 655 bacteria and potential applications. Environ. Technol. 31:943-956.

656 Wu, Q.Q., Wu, F.Z., Yang, W.Q., He, W., He, M., Zhao, Y.Y., Zhu, J.X. 2013. Effect 657 of seasonal snow cover on litter decomposition in the alpine forest. Chine. J. Plant. 658 Ecol. 37:296-305.

659 Xia, L., Wu, F.Z., Yang, W.Q. 2011. Contribution of soil fauna to mass loss of Abies 660 faxoniana leaf litter during the freeze-thaw season. Chine. J. Plant. Ecol. $661 \quad 35: 1127-1135$.

662 Yang, W.Q., Feng, R.F., Zhang, J., Wang, K.Y. 2007. Carbon stock and biochemical 663 properties in the organic layer and mineral soil under three subalpine forests in 664 Western China. Acta. Ecologica. Sinica. 27:4157-4165.

665 Yang, W.Q., Wang, K.Y., Kellomäki, S., Gong, H.D. 2005. Litter dynamics of three 666 subalpine forests in Western Sichuan. Pedosphere. 15:653-659.

667 Yang, W.Q., Wang, K.Y., Kellomäki, S., Zhang, J. 2006. Annual and monthly 668 variations in litter macronutrients of three subalpine forests in western China. 
669 Pedosphere. 16:788-798.

670 Young, I.M., and Crawford, J.W. 2004. Interactions and self-organization in the 671 soil-microbe complex. Science. 304:1634-1637.

672 Zhu, J.X., He, X.H., Wu, F.Z., Yang, W.Q., Tan B. 2012. Decomposition of Abies

673 faxoniana litter varies with freeze-thaw stages and altitudes in subalpine/alpine 674 forests of southwest China. Scand. J. Forest. Res. 27:586-596.

675 Zhu, J.X., Yang, W., He, X.H. 2013. Temporal dynamics of abiotic and biotic factors 676 on leaf litter of three plant species in relation to decomposition rate along a subalpine 677 elevation gradient. Plos One. 8:e62073.

678 Zinger, L., Shahnavaz, B., Baptist, F., Geremia, R.A., Choler P. 2009. Microbial 679 diversity in alpine tundra soils correlates with snow cover dynamics. ISME. J. $680 \quad 3: 850-859$ 
$681 \quad$ Figure captions

682 Figure 1. Dynamics of soil and air temperature during foliar litter decomposition 683 from October 26, 2010 to October 25, 2012.

684 Figure 2. Changes in the number of copies $\mathrm{g}^{-1}$ dry matter litter of the bacterial $16 \mathrm{~S}$ 685 rRNA gene with foliar litter decomposition. Error bars indicate the standard error of the mean (SE) of triplicate q-PCR reactions, and different letters denote significant differences between different stages.

Figure 3. Denaturing gradient gel electrophoresis (DGGE) profiles of bacterial communities at different stages of foliar litter decomposition. M, marker.

Figure 4. Principal component analysis using DGGE band intensities. Points represent individual samples with different times, and the diameter of each point is proportional to the measured Shannon-Wiener index value. Abbreviations: L, Larch; F, Fir; C, Cypress; B, Birch.

Figure 5. Neighbor-joining phylogenetic tree based on bacterial 16S rRNA gene sequences derived from the DGGE fingerprint profiles. The numbers at branch points indicate bootstrap percentages of the Kimura 2-parameter.

Figure 6. Relative abundance of the bacterial groups as foliar litter decomposition proceeds.

Figure 7. RDA ordination diagrams for the first two dimensions of the relationship with the bacterial community structure at the class level. 
Table 1. Chemical characteristics and temperature dynamics of foliar litter decomposition

\begin{tabular}{|c|c|c|c|c|c|c|c|c|c|c|c|c|c|c|}
\hline & & Day & $\begin{array}{c}\text { Moisture } \\
(\%)\end{array}$ & $\begin{array}{l}\text { Mass Loss } \\
\qquad(\mathrm{g})\end{array}$ & $\begin{array}{c}\mathrm{TC} \\
\left(\mathrm{g} \cdot \mathrm{kg}^{-1}\right)\end{array}$ & $\begin{array}{c}\mathrm{TN} \\
\left(\mathrm{g} \cdot \mathrm{kg}^{-1}\right)\end{array}$ & $\begin{array}{c}\mathrm{TP} \\
\left(\mathrm{g} \cdot \mathrm{kg}^{-1}\right)\end{array}$ & $\mathrm{C} / \mathrm{N}$ & $\mathrm{C} / \mathrm{P}$ & $\mathrm{N} / \mathrm{P}$ & $\begin{array}{l}\text { PAT } \\
\left({ }^{\circ} \mathrm{C}\right)\end{array}$ & $\begin{array}{l}\text { NAT } \\
\left({ }^{\circ} \mathrm{C}\right)\end{array}$ & $\begin{array}{c}\text { Du-AT } \\
\left({ }^{\circ} \mathrm{C}\right)\end{array}$ & $\begin{array}{l}\text { Air } \\
\left({ }^{\circ} \mathrm{C}\right)\end{array}$ \\
\hline \multirow[t]{4}{*}{ Larch } & W1 & 1 & $31.48 \pm 8.69$ & $1.26 \pm 0.19$ & $512.64 \pm 7.03$ & $8.60 \pm 0.07$ & $2.18 \pm 0.11$ & $59.62 \pm 0.58$ & $235.10 \pm 9.35$ & $3.94 \pm 0.19$ & 0.00 & -241.50 & -3.47 & -5.32 \\
\hline & G1 & 170 & $35.32 \pm 14.87$ & $2.47 \pm 0.18$ & $495.29 \pm 39.59$ & $8.40 \pm 0.15$ & $2.14 \pm 0.16$ & $58.95 \pm 3.70$ & $231.00 \pm 2.71$ & $3.93 \pm 0.23$ & 938.53 & 0.00 & 6.67 & 9.12 \\
\hline & W2 & 371 & $31.80 \pm 11.41$ & $3.62 \pm 0.04$ & $499.56 \pm 12.84$ & $7.73 \pm 0.55$ & $2.12 \pm 0.11$ & $64.82 \pm 3.23$ & $236.40 \pm 8.00$ & $3.65 \pm 0.25$ & 0.00 & -230.23 & -3.48 & -5.74 \\
\hline & $\mathrm{G} 2$ & 542 & $20.83 \pm 4.18$ & $3.93 \pm 0.07$ & $464.84 \pm 1.58$ & $8.18 \pm 0.11$ & $2.11 \pm 0.03$ & $56.81 \pm 0.89$ & $220.41 \pm 3.30$ & $3.88 \pm 0.03$ & 1000.60 & 0.00 & 8.11 & 8.65 \\
\hline \multirow[t]{4}{*}{ Fir } & W1 & 1 & $26.29 \pm 8.14$ & $0.84 \pm 0.14$ & $486.46 \pm 5.19$ & $10.59 \pm 0.15$ & $1.35 \pm 0.03$ & $45.96 \pm 1.14$ & $359.61 \pm 11.21$ & $7.83 \pm 0.19$ & 0.00 & -241.50 & -3.47 & -5.32 \\
\hline & G1 & 170 & $60.00 \pm 6.03$ & $2.10 \pm 0.23$ & $479.6 \pm 24.04$ & $11.24 \pm 0.03$ & $1.36 \pm 0.06$ & $42.62 \pm 2.17$ & $352.74 \pm 31.75$ & $8.27 \pm 0.35$ & 938.53 & 0.00 & 6.67 & 9.12 \\
\hline & W2 & 371 & $60.82 \pm 2.00$ & $3.02 \pm 0.06$ & $454.02 \pm 12.08$ & $10.98 \pm 0.24$ & $1.16 \pm 0.02$ & $41.34 \pm 0.20$ & $391.14 \pm 5.04$ & $9.46 \pm 0.08$ & 0.00 & -230.23 & -3.48 & -5.74 \\
\hline & $\mathrm{G} 2$ & 542 & $65.52 \pm 0.67$ & $3.28 \pm 0.06$ & $429.05 \pm 0.84$ & $10.9 \pm 0.09$ & $1.15 \pm 0.02$ & $39.36 \pm 0.38$ & $373.77 \pm 8.66$ & $9.50 \pm 0.14$ & 1000.60 & 0.00 & 8.11 & 8.65 \\
\hline \multirow[t]{4}{*}{ Cypress } & W1 & 1 & $17.66 \pm 6.91$ & $0.84 \pm 0.19$ & $492.12 \pm 7.28$ & $9.82 \pm 0.15$ & $1.45 \pm 0.00$ & $50.13 \pm 0.05$ & $339.45 \pm 5.72$ & $6.77 \pm 0.12$ & 0.00 & -241.50 & -3.47 & -5.32 \\
\hline & G1 & 170 & $48.58 \pm 18.79$ & $2.27 \pm 0.18$ & $501.53 \pm 0.91$ & $9.61 \pm 0.03$ & $1.40 \pm 0.05$ & $52.20 \pm 0.56$ & $357.68 \pm 14.75$ & $6.85 \pm 0.21$ & 938.53 & 0.00 & 6.67 & 9.12 \\
\hline & W2 & 371 & $40.79 \pm 9.13$ & $3.41 \pm 0.30$ & $476.71 \pm 20.23$ & $9.44 \pm 0.23$ & $1.42 \pm 0.07$ & $50.51 \pm 0.94$ & $335.40 \pm 3.92$ & $6.64 \pm 0.19$ & 0.00 & -230.23 & -3.48 & -5.74 \\
\hline & $\mathrm{G} 2$ & 542 & $15.60 \pm 1.53$ & $3.90 \pm 0.06$ & $447.98 \pm 30.13$ & $9.30 \pm 0.16$ & $1.45 \pm 0.12$ & $48.14 \pm 2.67$ & $308.60 \pm 6.17$ & $6.43 \pm 0.44$ & 1000.60 & 0.00 & 8.11 & 8.65 \\
\hline \multirow[t]{4}{*}{ Birch } & W1 & 1 & $20.83 \pm 4.18$ & $1.05 \pm 0.12$ & $465.58 \pm 14.47$ & $14.07 \pm 0.13$ & $0.90 \pm 0.04$ & $33.08 \pm 0.72$ & $517.66 \pm 39.73$ & $15.63 \pm 0.86$ & 0.00 & -241.50 & -3.47 & -5.32 \\
\hline & G1 & 170 & $65.52 \pm 0.67$ & $2.79 \pm 0.19$ & $439.72 \pm 1.68$ & $14.43 \pm 0.37$ & $0.97 \pm 0.01$ & $30.49 \pm 0.88$ & $452.53 \pm 6.71$ & $14.85 \pm 0.48$ & 938.53 & 0.00 & 6.67 & 9.12 \\
\hline & W2 & 371 & $15.60 \pm 1.53$ & $4.10 \pm 0.09$ & $426.67 \pm 21.67$ & $14.52 \pm 1.20$ & $0.97 \pm 0.07$ & $29.44 \pm 1.06$ & $441.36 \pm 22.06$ & $15.02 \pm 1.17$ & 0.00 & -230.23 & -3.48 & -5.74 \\
\hline & $\mathrm{G} 2$ & 542 & $68.86 \pm 2.08$ & $4.45 \pm 0.08$ & $420.58 \pm 16.37$ & $15.21 \pm 0.94$ & $1.04 \pm 0.4$ & $27.67 \pm 0.75$ & $404.32 \pm 16.20$ & $14.63 \pm 0.97$ & 1000.60 & 0.00 & 8.11 & 8.65 \\
\hline
\end{tabular}

Abbreviations: $\mathrm{W} 1,1^{\text {st }}$ winter; G1, $1^{\text {st }}$ growing season; W2, $2^{\text {nd }}$ winter; $\mathrm{G} 2,2^{\text {nd }}$ growing season; TC, total organic carbon; TN, total nitrogen; TP, total phosphorus; PAT, positive accumulated

temperature; NAT, negative accumulated temperature; Du-AT, duration average temperature. 
Table 2. Correlation analyses among the abundance of bacteria, C, N, P, degree-days, and average temperature.

\begin{tabular}{cccccc}
\hline & $\mathrm{W} 1$ & $\mathrm{G} 1$ & $\mathrm{~W} 2$ & $\mathrm{G} 2$ & Whole Research \\
\cline { 2 - 5 } Log ratio of bacteria & $0.801^{* *}$ & $0.892^{* *}$ & $0.794^{* *}$ & $0.930^{* *}$ & $0.627^{* *}$ \\
Moisture & $-0.439^{*}$ & $-0.698^{* *}$ & -0.414 & 0.013 & $-0.361^{* *}$ \\
Mass Loss & -0.103 & 0.150 & $0.799^{* *}$ & -0.174 & $-0.479^{* *}$ \\
TC & $-0.610^{* *}$ & 0.383 & $-0.618^{*}$ & $0.413^{*}$ & 0.081 \\
TN & $0.740^{* *}$ & -0.398 & $0.870^{* *}$ & $-0.484^{*}$ & $0.230^{*}$ \\
TP & $-0.636^{* *}$ & $0.722^{* *}$ & $-0.594^{*}$ & $0.566^{* *}$ & $-0.240^{*}$ \\
C/N & $-0.693^{* *}$ & $0.477^{*}$ & $-0.754^{* *}$ & $0.545^{* *}$ & -0.182 \\
C/P & $0.726^{* *}$ & $-0.643^{* *}$ & $0.665^{* *}$ & $-0.551^{* *}$ & $0.409^{* *}$ \\
N/P & $0.754^{* *}$ & $-0.472^{*}$ & $0.825^{* *}$ & $-0.507^{*}$ & $0.309^{* *}$ \\
PAT & - & - & - & - & $-0.340^{* *}$ \\
NAT & - & - & - & - & $-0.353^{* *}$ \\
Du-AT & - & - & - & - & $-0.339^{* *}$ \\
Air & - & - & - & - & $-0.331^{* *}$ \\
\hline
\end{tabular}

*, Correlation is significant at the 0.01 level (two-tailed). **, Correlation is significant at the 0.05 level (two-tailed). 
Table 3. Bacterial diversity index of foliar litter decomposition.

\begin{tabular}{|c|c|c|c|c|}
\hline & & Bands number & Shannon-Wiener Index & Simpson Index \\
\hline \multirow[t]{4}{*}{ Larch } & W1 & 11 & 2.387 & 0.093 \\
\hline & G1 & 39 & 3.584 & 0.029 \\
\hline & W2 & 11 & 2.348 & 0.099 \\
\hline & G2 & 18 & 2.865 & 0.058 \\
\hline \multirow[t]{4}{*}{ Fir } & W1 & 13 & 2.456 & 0.093 \\
\hline & G1 & 41 & 3.684 & 0.026 \\
\hline & W2 & 23 & 3.046 & 0.051 \\
\hline & $\mathrm{G} 2$ & 32 & 3.413 & 0.034 \\
\hline \multirow[t]{4}{*}{ Cypress } & W1 & 17 & 2.571 & 0.093 \\
\hline & G1 & 34 & 3.490 & 0.031 \\
\hline & W2 & 29 & 3.253 & 0.043 \\
\hline & $\mathrm{G} 2$ & 22 & 3.060 & 0.048 \\
\hline \multirow[t]{4}{*}{ Birch } & W1 & 17 & 2.786 & 0.064 \\
\hline & G1 & 29 & 3.318 & 0.037 \\
\hline & W2 & 41 & 3.645 & 0.028 \\
\hline & $\mathrm{G} 2$ & 29 & 3.312 & 0.038 \\
\hline
\end{tabular}




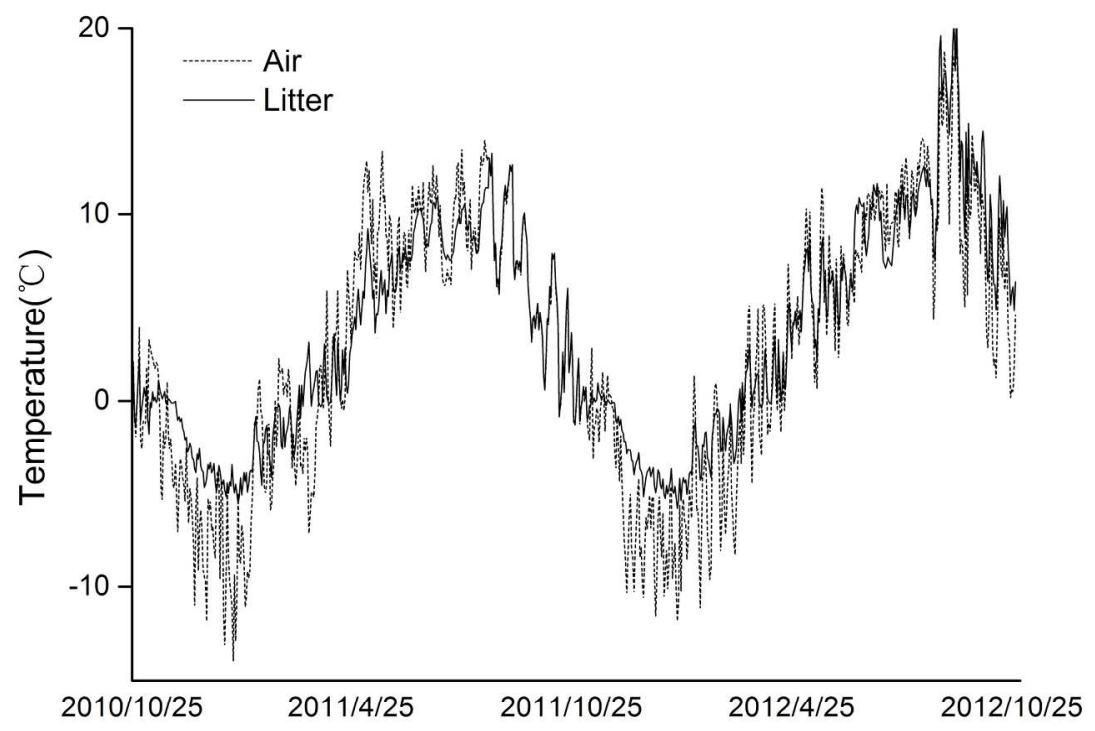

Figure 1. Dynamics of soil and air temperature during foliar litter decomposition from October 26, 2010 to October 25, 2012.

$202 \times 141 \mathrm{~mm}(300 \times 300$ DPI $)$ 


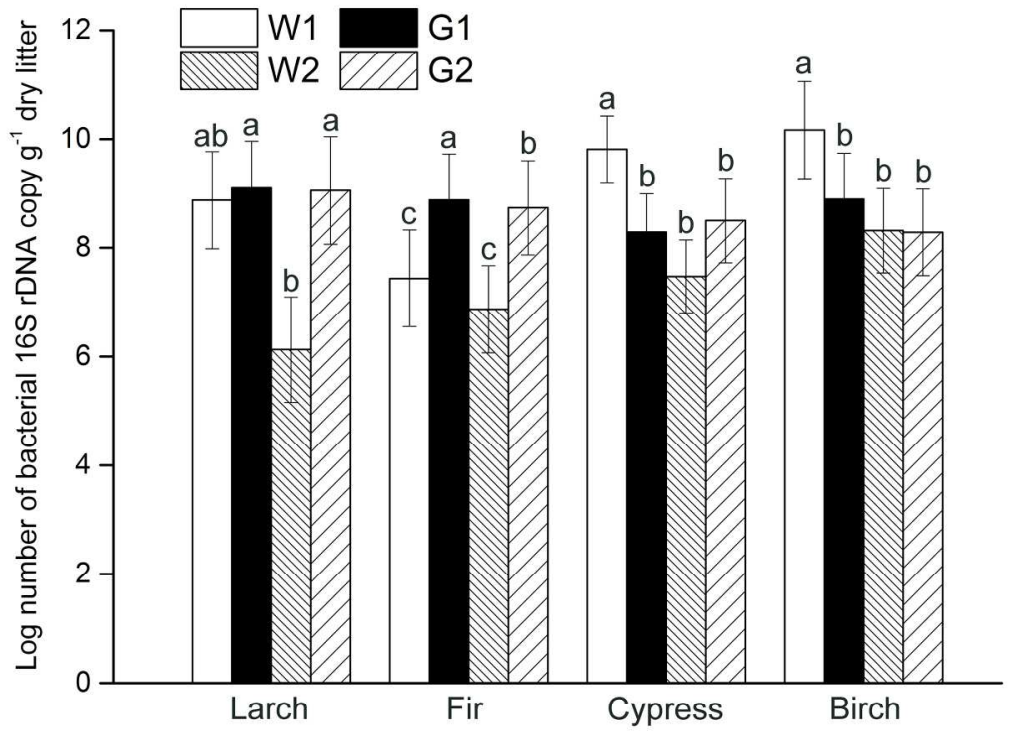

Figure 2. Changes in the number of copies g-1 dry matter litter of the bacterial $16 S$ rRNA gene with foliar litter decomposition. Error bars indicate the standard error of the mean (SE) of triplicate q-PCR reactions, and different litters denote significant differences between different stages. $202 \times 141 \mathrm{~mm}(300 \times 300$ DPI $)$ 


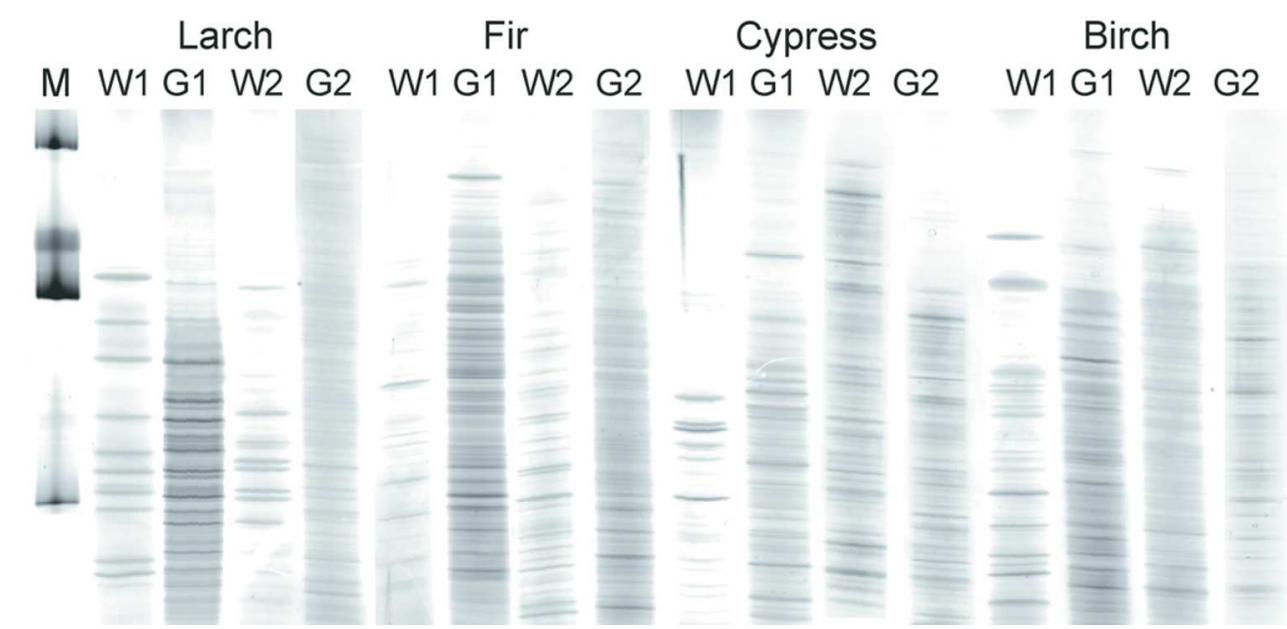

Figure 3. Denaturing gradient gel electrophoresis (DGGE) profiles of bacterial communities at different stages of foliar litter decomposition. M, marker.

$89 \times 42 \mathrm{~mm}$ (300 x 300 DPI) 


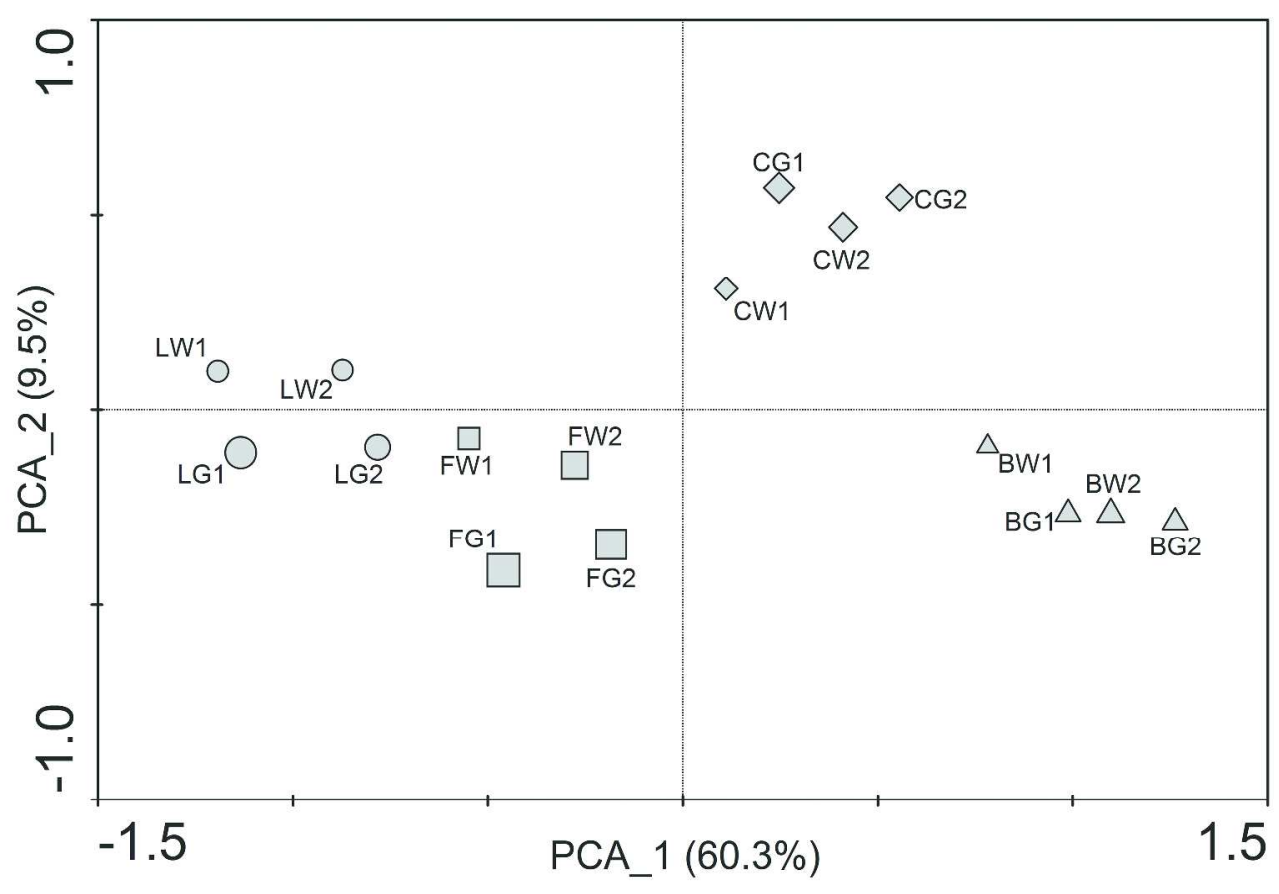

Figure 4. Principal component analysis using DGGE band intensities. Points represent individual samples with different times, and the diameter of each point is proportional to the measured Shannon-Wiener index value. Abbreviations: L, Larch; F, Fir; C, Cypress; B, Birch. $2414 \times 1690 \mathrm{~mm}(72 \times 72$ DPI $)$ 

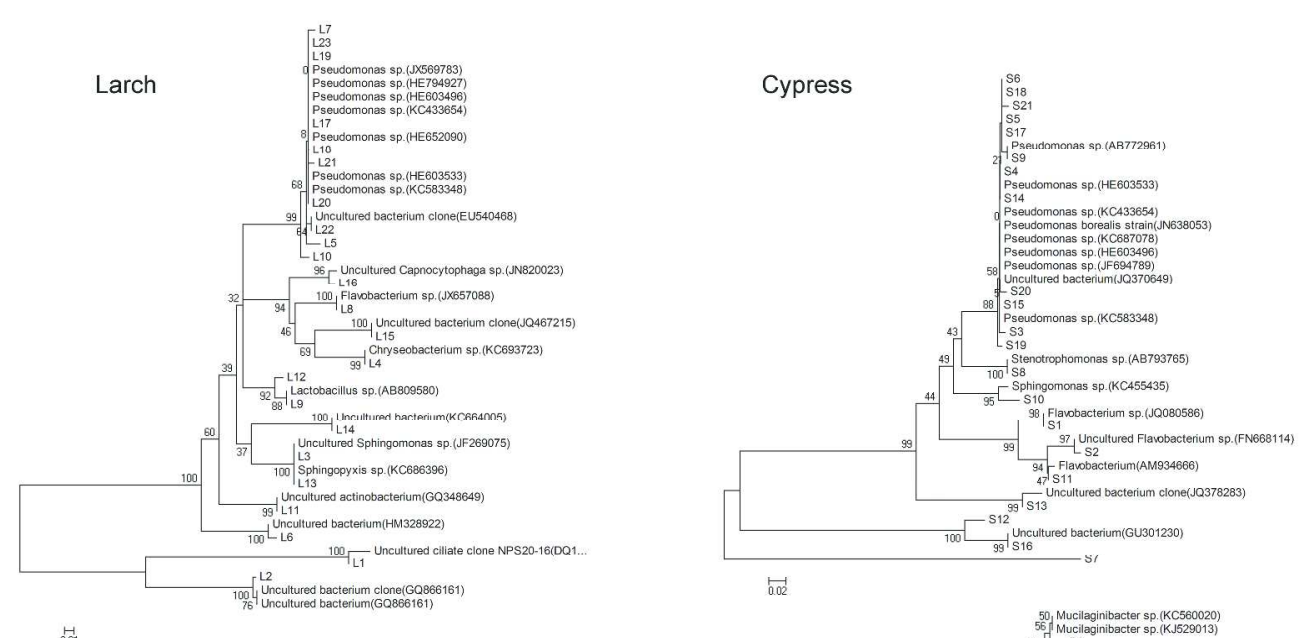

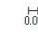
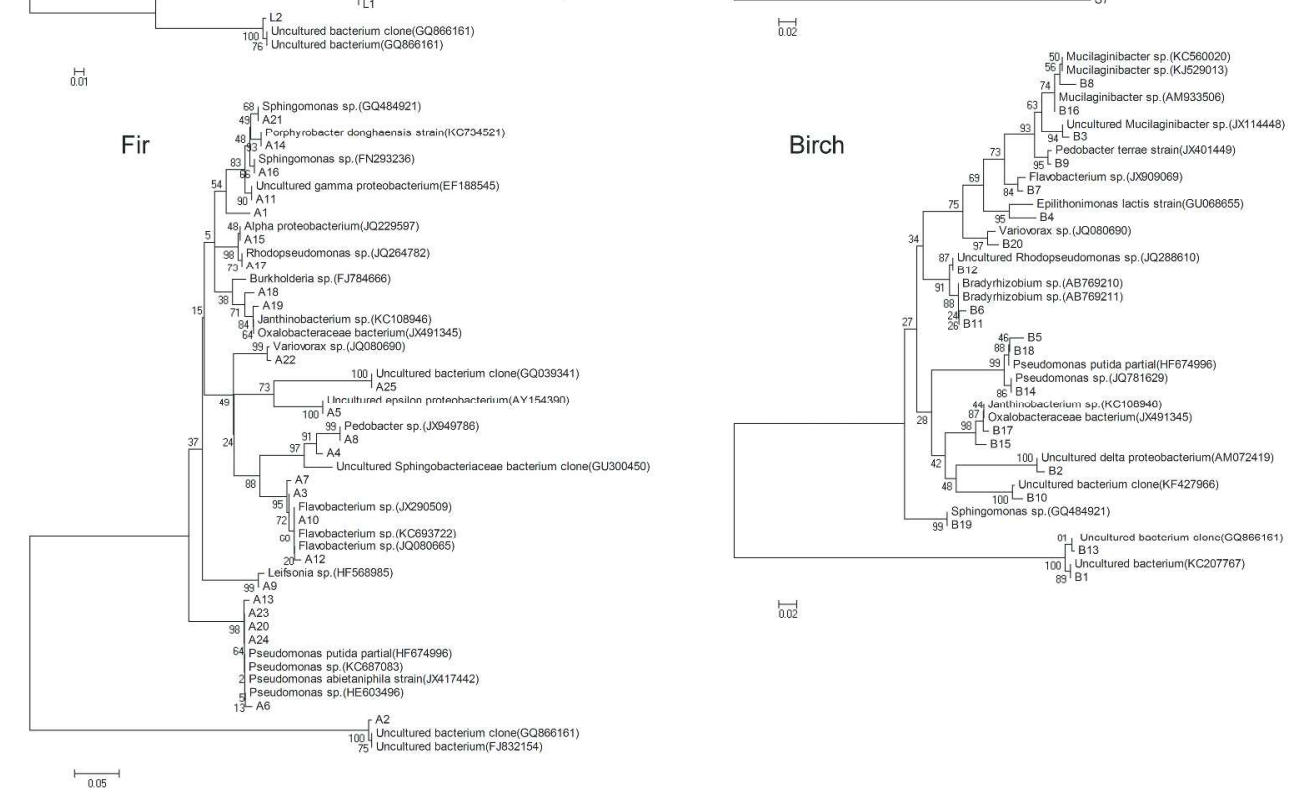

$\stackrel{6.02}{0.02}$

Figure 5. Neighbor-joining phylogenetic tree based on bacterial 16S rRNA gene sequences derived from the DGGE fingerprint profiles. The numbers at branch points indicate bootstrap percentages of the Kimura 2parameter.

$385 \times 400 \mathrm{~mm}(300 \times 300 \mathrm{DPI})$ 


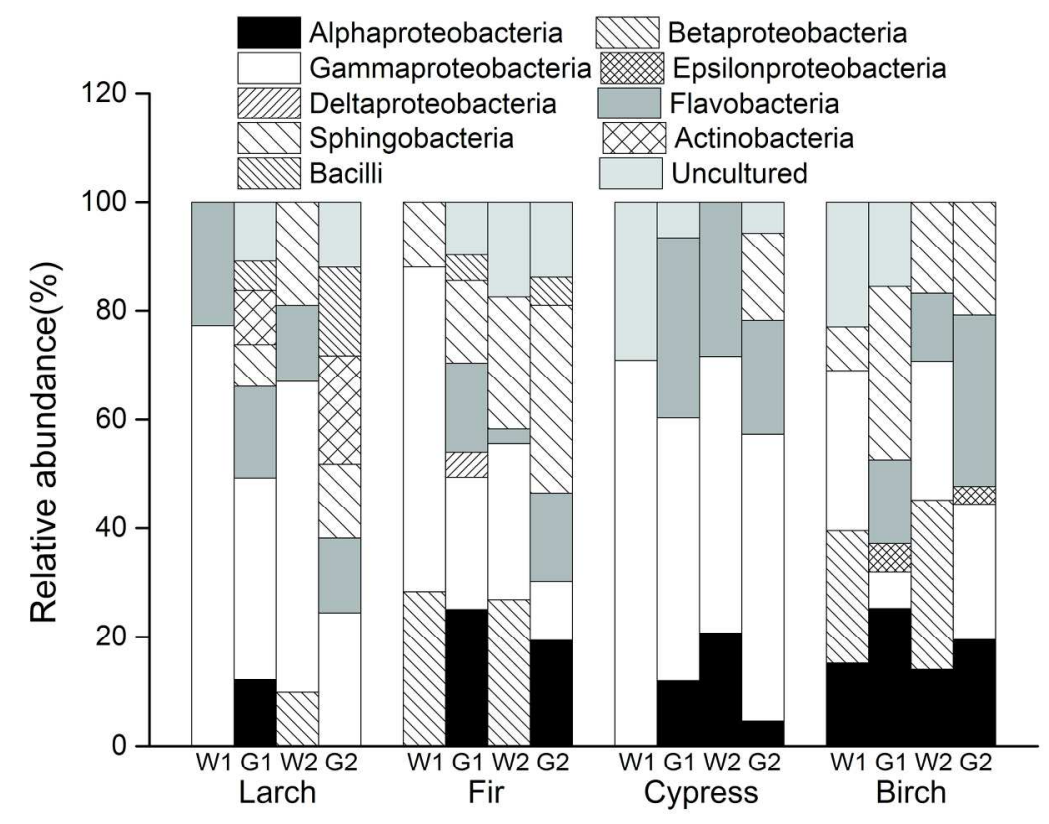

Figure 6. Relative abundance of the bacterial groups as foliar litter decomposition proceeds. $202 \times 141 \mathrm{~mm}(300 \times 300$ DPI) 

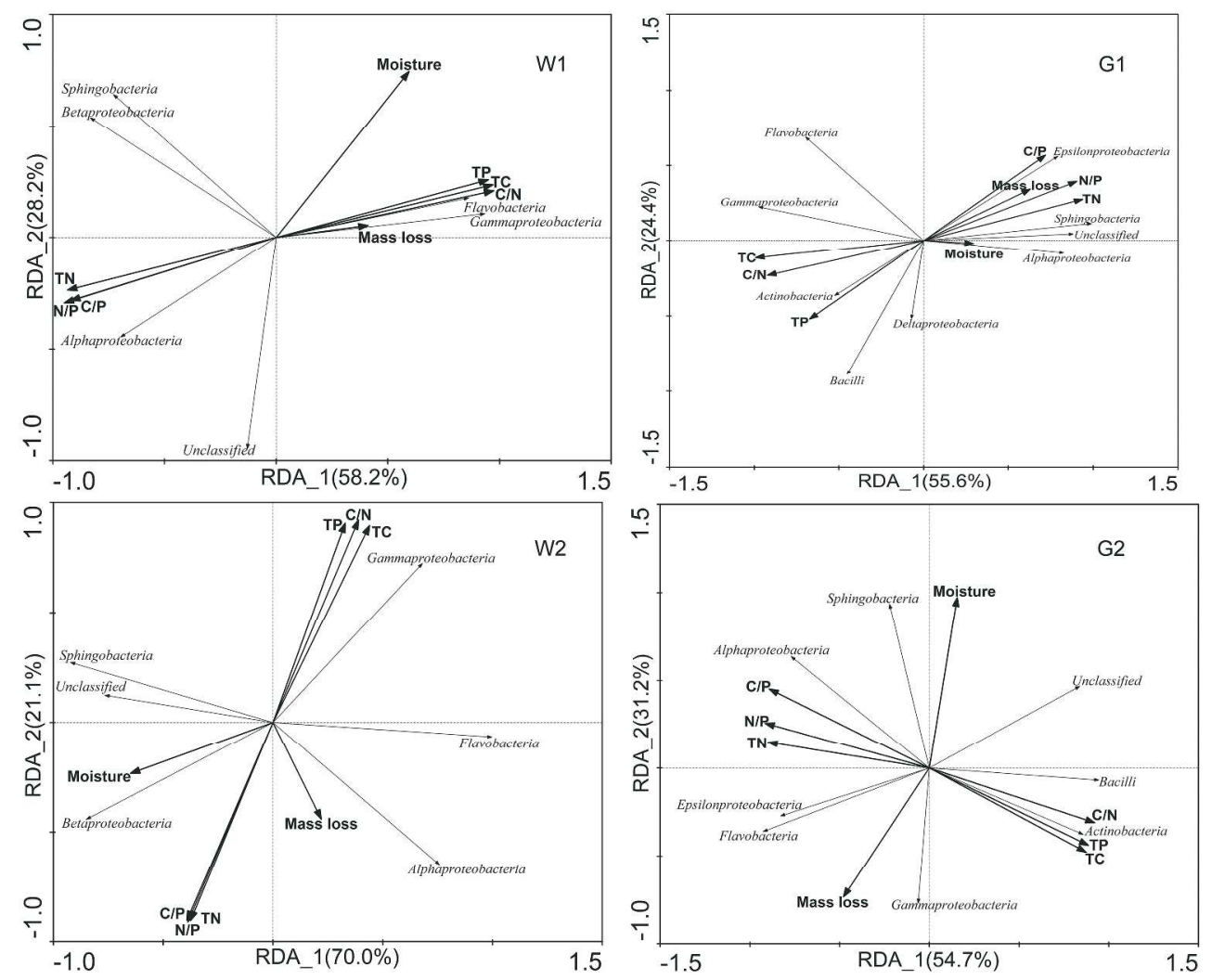

Figure 7. RDA ordination diagrams for the first two dimensions of the relationship with the bacterial community structure at the class level.

$1164 \times 948 \mathrm{~mm}(72 \times 72 \mathrm{DPI})$ 